\title{
The Rectification Measures of "Big Sheds" in China*
}

\author{
Haiying $\mathrm{Yu}$ \\ Southwest Minzu University \\ Chengdu, China
}

\author{
Lilan Qiu \\ Southwest Minzu University \\ Chengdu, China
}

\begin{abstract}
The purpose of the study is to analyze the causes of the "big sheds" in China, give reasonable suggestions for the rectification of "big sheds", and promote the implementation of the "special remediation plan for big sheds", and more importantly, prevent the revival of big sheds that have been rectified, ultimately, promote the completion of the rural revitalization strategy. Research method: data analysis method. Research results: the main reason for the "big sheds" is that its low cost can generate high returns. Research conclusions: the rectification of "big sheds" should be tailored to local conditions, and requires government departments to make strict supervision and people to abide by the law consciously.
\end{abstract}

Keywords-big sheds; greenhouse; farmland remediation; non-agricultural facilities

\section{INTRODUCTION}

"Big sheds" is a kind of non-agricultural facility building in the name of developing agriculture. Most of them are commercial houses building in arable land in agricultural greenhouses, which surface is covered with a layer of plastic film. What's more, the land cost and construction cost are very low.

$70 \%$ of the land occupied by "big sheds" is arable land, and even permanent basic farmland, which is an illegal profit-making construction. In August 2018, the Ministry of Natural Resources and the Ministry of Agriculture and Rural Affairs jointly launched a special rectification plan for "big sheds". By March 17, 2019, the percentage of the rectified "big sheds" has achieved $80 \%$.

Before the 1960s, in the period of rapid industrial development, in order to meet the needs of industrial development, the United States also occupied large-scale arable land for non-agricultural construction [1]. As for agricultural land, the US government launched agricultural zoning, set up buffer zone for agricultural zone, and managed the agricultural land in a unified manner [2]. The per capita arable land area in Japan is also extremely limited. With the development of urbanization, arable land has been damaged to varying degrees [3]. Subsequently, Japan established a complete land system for the protection of cultivated land.

In China, as early as 2006, Beijing has discovered that such "agricultural facilities" that violate the law and increase the residential function have been rented, sold, and illegally

*Fund: "Study on Land Use Benefit Evaluation of Renovation of Shack Areas in Chengdu" (CX2019SZ35) transferred, and have been rectified. However, in recent years, "big sheds" have appeared again. There are 2,799 "big sheds" in the Beijing-Tianjin-Hebei region. The number of the "big sheds" is 36,675,000, involving $9869 \mathrm{mu}$ of land. Sichuan's "big sheds" cover an area of nearly $10,000 \mathrm{mu}$, Henan, Anhui, Shandong, Shanxi and other places have a large number of "big sheds." A total of 168,000 "big sheds" were found in the national survey, involving 130,000 mu of arable land. The "big sheds" is not only wider, but also more serious.

\section{THE REASONS FOR THE EMERGENCE OF "BIG SHEDS"}

The "big sheds" is mainly produced in terms of demand and supply.

On the demand side, on the one hand, due to the increasing pressure on living and the anxiety on working of urban residents, urban residents are full of yearning for leisurely lifestyle in rural. On the other hand, due to the rising housing prices in cities, especially in the first-tier cities, the "big sheds" are more affordable by urban residents, which in the suburbs of the cities. According to statistics, $70 \%$ of the buyers of "big sheds" are urban residents because they are more capable and more demanding than rural residents to purchase "big sheds".

On the supply side, there are four reasons: First, the "big sheds" developers do not have to pay a large amount of land fees for transferring, and only need a small amount of development costs to create a comfortable and idyllic "village villa". Second, compared with the hard work of one year, in exchange for the annual income of crops of 10,000 to 20,000, farmers are also more inclined to rent and sell "big sheds", which are easy and high-yielding behaviors, and most of them can get a large amount of income in one time. Third, the development of agricultural greenhouses can also apply for government subsidies. For example, Beijing subsidizes 30,000 yuan and 10,000 yuan per mu of high-rise solar greenhouses and steel frame greenhouses. Fourth, the "big shed" itself has strong concealment. The sellers tell the purchaser that they can make any renovations to the interior of the "big shed", but they must not change their appearance.

\section{RENOVATION OF THE BASIC PRINCIPLES AND OBJECTIVES OF THE "BIG SHEDS"}

The fundamental purpose of rectifying the "big sheds" is to not reduce food production, ensure national food security, and achieve sustainable development. The process of remediating the "big sheds" contains several key points: 


\section{A. Ensuring Food and Income}

The construction of "big shed" has increased a large amount of income for farmers. It is illegal to occupy cultivated land for non-agricultural construction. The "big shed" must be demolished, but the land after the "big shed" is demolished, even if it is reclaimed. Farmers holding land may have idle land. Even if farmers grow crops, the income from planting will be lower than that of "big sheds", which will inevitably reduce the income of farmers. In order to ensure the increase of farmers' income, industrial guidance and technical guidance should be carried out for farmers, which is a problem that must be paid attention to meet the idyllic needs of urban residents.

\section{B. Meeting the Idyllic Needs of Urban Residents}

From the perspective of social psychology, the development of Chinese society is accelerating, the pressure on urban residents is increasing, and the yearning for rural life is becoming more common. Moreover, according to the theory of counter-urbanization proposed by geographer Bonn, China will also experience de-urbanization. Suburban and rural land need to be able to accommodate a large number of urban populations. However, China's household registration system and urban-rural dualism limit the right of urban residents to enjoy rural land. . In order to solve the urban residents' longing for rural pastoral needs, they can be combined with China's "three land" reforms, for example, the development of sightseeing agriculture.

\section{Paying Attention to the Problems of Suburban and Urban-rural Integration}

The problem of concentrated land in China lies in the suburban and urban-rural integration. The "big shed" is in the suburbs, and the discovery of the "big shed" has made us more concerned about the urban-rural integration. The urban-rural integration is at the intersection of the urban and rural dual systems, which is the point of inspiring contradictions. The improvement of the system is the fundamental way to resolve the contradictions. For example, all the systems of land make the government have a leading role. If it is added to a third-party assessment agency for supervision, it will not only solve the problem of rectifying the "big sheds" but also create other conditions for solving land problems.

\section{Strengthening Technological Innovation and Improving Land Work Efficiency}

In response to the "big sheds" problem, the application and enhancement of remote sensing technology should be enhanced, and the land management information system should be improved. Establishing a sound land information system is an important means of effective land management. Through the process of discovering problems and solving problems, developing new science and technology, improving the efficiency of landholders and land users, and gradually improving China's land management system.

\section{MEASURES FOR THE RECTIFICATION OF "Big SHEDS" IN CHINA}

\section{A. Demolition of Illegally Built "Big Sheds" for Rehearsal and Guidance}

It is only the first step to dismantle and rehabilitate all the illegally built "big sheds". For the sake of agricultural economic development and the security of the food strategy, it is necessary to properly guide the farmers to dismantle the "big sheds". The losses suffered can be minimized and can be efficiently profitable in agricultural production.

\section{B. Blocking Publicity Channels}

The propaganda of "big sheds" is mostly promoted by small stickers and online channels. The Ministry of Natural Resources and the Ministry of Agriculture and Rural Affairs have required enterprises not to publish "big sheds" advertising information, and the information on agricultural sheds must not contain inhabitable information. Photographs of agricultural greenhouses containing living facilities shall not be published. Websites may not publish rumors or "title party" and mislead netizens. Compared with urban housing, the promotion of cheap "big sheds" can even lead to social stability.

\section{Strengthening the Legal Awareness of Social Land}

Part of the reason for the "big sheds" is that the public does not understand the law, and the propaganda of the "Land Management Law" should be strengthened among the masses. The propaganda objects are mainly divided into three categories: farmers, enterprises and government officials. It is necessary to strengthen the awareness of the law, especially the promotion of the control of cultivated land and basic farmland use in rural areas; to deal with the strict land use land use regulation of real estate development enterprises, and severely punish enterprises that violate the regulations; many local governments have initiated accountability procedures. According to the rules and regulations, the relevant leaders are held accountable and accountable.

\section{Adhering to the Red Line of Cultivated Land and Enhancing Land Use Control}

The safety of cultivated land is the guarantee of food security. The red line of cultivated land cannot be touched. It is necessary to strengthen supervision over the use of enhanced control. In fact, the reason why the size of the "big sheds" is so large is that the supervision of the competent government departments is not in place. Because of its strong concealment, the "big sheds" are mostly located on farms in the suburbs, away from the supervision of government units. What is important is not only the demolition supervision of the existing "big shed", but also the rebound of the "big sheds". For example, the Tianjin Municipal Government issued the "Notice on the Governance of 'Gard Houses' as a Key Point to Further Strengthen the Supervision of Land Use and Land Use for Agricultural Facilities", and established a file management system based on the principle of "one town, one village, one book, one house, one household and one 
file". The Ministry of Land and Resources of Hebei Province issued the "Announcement on Thoroughly Investigating and Renovating the "Large House", and the people found that it was possible to report the violation of the "big sheds".

\section{CONCLUSION}

The rectification of rural "big sheds" is a new exploration and improvement of the land management system. Rural land is not only the capital for the revitalization and development of China's rural areas, but also an important support for the continued advancement of the entire society in China.

Arable land should be legally and rationally nonagricultural. For cultivated land that has been detrimental to agricultural cultivation or land with extremely low profitability, it may be considered to change the use of cultivated land, but it is necessary to implement legal channels and make rational planning and allocation so that the agricultural land can exert greater social and economic benefits and reduce waste of resources.

The solution of more land issues, including the "big sheds", must consider the relationship between the masses, enterprises and the government. It is necessary to ensure the long-term stability of the society. Every measure needs to be tested by practice. With the development of society, land will have to carry more functions, and new science and technology will be needed for functional adjustment and planning. For agriculture, it is necessary to introduce capital to the countryside. It is also important to cultivate farmers who can use new technologies to develop agriculture, to give full play to the original advantages of farmers and to stimulate potential labor skills of farmers, and to fundamentally guarantee food and to increase income and help rural revitalization.

\section{REFERENCES}

[1] Zhiyang Liu, "On the Protection of Agricultural Land in the Process of Urbanization - American Experience and Reference" Development forum, vol. 9, pp. 37-39, 2003.

[2] Huanzhao Zhang, Jiating Wang, Shuli Wang, "Main Characteristics and Enlightenment of American Land Use Planning Legislation and Establishment" Land Resources Guide, 3rd ed., 2007, pp.68-71.

[3] Daquan Huang, Weiyuan Zheng, "The Enlightenment of Overseas Urbanization and Cultivated Land Protection to China," Chinese Land Science, 3rd ed.,vol.19, 2005, pp. 38-43. 